\title{
Quorum Sensing versus Quenching Bacterial Isolates Obtained from MBR Plants Treating Leachates from Municipal Solid Waste
}

\author{
Albert Soler ${ }^{1}$ (1) , Lucía Arregui ${ }^{1, *}$, Miguel Arroyo ${ }^{2}$, José Antonio Mendoza ${ }^{3}$, Andrea Muras ${ }^{4}$ (D), \\ Cristina Álvarez ${ }^{5}$, Cristina García-Vera ${ }^{5}$, Domingo Marquina ${ }^{1}$, Antonio Santos ${ }^{1}$ and \\ Susana Serrano ${ }^{1}$ \\ 1 Department of Genetics, Physiology and Microbiology, Complutense University of Madrid, 28040 Madrid, \\ Spain; albert.sol.her@gmail.com (Al.S.); dommarq@ucm.es (D.M.); ansantos@ucm.es (An.S.); \\ suserra@ucm.es (S.S.) \\ 2 Department of Biochemistry and Molecular Biology I, Complutense University of Madrid, 28040 Madrid, \\ Spain; arroyo@ucm.es \\ 3 Department of Chemical and Nuclear Engineering, Polytechnic University of Valencia, 46022 Valencia, \\ Spain; jamendoz@iqn.upv.es \\ 4 Department of Microbiology and Parasitology_CIBUS, Universidade de Santiago de Compostela, \\ 15782 Santiago de Compostela, Spain; andrea.muras@usc.es \\ 5 URBASER S.A., Camino de Hormigueras, 171, 28031 Madrid, Spain; calvarezr@urbaser.com (C.Á.); \\ cgvera@urbaser.com (C.G.-V.) \\ * Correspondence: arregui@ucm.es; Tel.: +34-913-944-966
}

Received: 16 April 2018; Accepted: 15 May 2018; Published: 18 May 2018

\begin{abstract}
Quorum sensing (QS) is a mechanism dependent on bacterial density. This coordinated process is mediated by the synthesis and the secretion of signal molecules, called autoinducers (AIs). $\mathrm{N}$-acyl-homoserine lactones (AHLs) are the most common AIs that are used by Gram-negative bacteria and are involved in biofilm formation. Quorum Quenching (QQ) is the interference of QS by producing hydrolyzing enzymes, among other strategies. The main objective of the present study was to identify QS and QQ strains from MBR wastewater treatment plants. A total of 99 strains were isolated from two Spanish plants that were intended to treat leachate from municipal solid waste. Five AHL producers were detected using AHL biosensor strains (Chromobacterium violaceum CV026 and Agrobacterium tumefaciens NT1). Fifteen strains of seventy-one Gram-positive were capable of eliminating or reducing at least one AHL activity. The analysis of $16 \mathrm{~S}$ rRNA gene sequence showed the importance of the Pseudomonas genus in the production of biofilms and the relevance of the genus Bacillus in the disruption of the QS mechanism, in which the potential activity of lactonase or acylase enzymes was investigated with the aim to contribute to solve biofouling problems and to increase the useful lifespan of membranes.
\end{abstract}

Keywords: quorum sensing; quorum quenching; AHL; biofouling; MBR; wastewater treatment

\section{Introduction}

Microorganisms have developed complex communication systems to produce, and, in turn, respond to extracellular signals that are secreted by others [1-3]. This microbial communication system, called Quorum Sensing (QS), is the ability to sense their population density through the synthesis and secretion of small molecules, called AutoInducers (AIs) [4-6]. Although different types of signal molecules have been described [7], the best characterized QS signals are the $N$-acyl homoserine lactones (AHLs). These QS signals are molecules of low molecular mass that are characterized by 
having a conserved lactone moiety and a variable acyl side chain (between 4 and 18 carbons) [8]. Despite of AHLs are QS signals that are considered to be typical of Gram-negative bacteria; they are also produced by the Gram-positive strain Exiguobacterium MPO [9]. QS controls, via gene expression modulation, a wide range of activities, such as pathogenesis $[10,11]$, bioluminescence, biosynthesis of antibiotics, mobility, or biofilm formation $[12,13]$.

Nowadays, membrane bioreactors (MBR) are becoming an advanced feasible treatment system for both industrial and urban wastewater treatment plants (WWTP) [14-16]. This system is a combination of a biological degradation process, primarily an activated sludge process, along with a solid-liquid separation by micro- or ultrafiltration membranes of pore size ranging from 0.05 to $0.4 \mu \mathrm{m}$ [17]. MBR systems allow for working with high concentrations of mixed liquor suspended solids, and also obtaining low sludge production and excellent effluent qualities necessary for agricultural or domestic uses or to simply incorporate the treated wastewater back into the water cycle with increased guarantees. Despite the advantages described, there are several problems that are hindering the implementation of such systems. Firstly, it has been found that the high economical cost of the membranes make them difficult to use in large scale projects [18]. Secondly, membrane fouling, of chemical, biological, and physical origin is considered to be the biggest obstacle to the implementation of industrial-scale MBR systems at a higher extent [19].

The problem of membrane biofouling that is produced by Gram-negative bacteria could be considered to be related with QS, since it has been identified as one of the mechanisms controlling bacterial biofilm development and play a key role in the formation and maturation of numerous bacterial species biofilms [20,21]. Biofilm formation occurs by the accumulation of different microorganisms that are surrounded by an extracellular matrix consisting of secreted proteins, nucleic acids, polysaccharides, and dead cells. It generates a progressive loss in the efficiency of the membranes [22].

An effective technique for membrane biofouling control, which is based on the enzymatic degradation of signal molecules (AHLs) or Quorum Quenching (QQ), has been proposed [21,23-26]. QQ is a mechanism that can interfere with any QS-regulated phenotype [27]. At present, four types of enzymes that can degrade AHLs are known [6]: decarboxylases, deaminases, lactonases, and acylases. However, acylases and lactonases seem to be the most promising QQ activities for biotechnological and medical applications [28]. Acylases, which hydrolyze the amide bond generating a free fatty acid and the homoserine lactone ring [27,29,30], have been identified in Streptomyces sp. [31], Pseudomonas aeruginosa [32], or Bacillus cereus [33], among others. Lactonases hydrolyze the core lactone ring of AHL signaling molecules and they have been identified in Acinetobacter sp. [34], Rhodococcus sp. [35,36], or Agrobacterium tumefaciens [37]. Up to now, numerous lactonases have been described in genus Bacillus sp. [38-43]. All of them belong to most abundant cluster among the AHL-degrading enzymes, the metallo-beta-lactamase (MBL) superfamily. However, several unrelated families with AHL-lactonase activity belong to the phosphotriesterase (PTE) family or the $\alpha / \beta$-hydrolase-fold family have been described [28].

Understanding microbial population development in MBR treating leachates from municipal solid wastes is challenging due to the complexity of waste materials that are deposited and the temporal heterogeneity. In the present study, QS and QQ bacteria were isolated from samples of two MBR plants with biofouling problems that are located in Spain with the aim of increasing the life expectancy of the ultrafiltration membranes. The biological control of this problem, through the use of native bacterial isolates with QQ activity, has been proposed as a potential mechanism that could prevent biofouling on membranes of MBR systems, reducing environmental damages, and minimizing operational costs [44]. 


\section{Materials and Methods}

\subsection{Wastewater Treatment Plants}

Two full-scale MBRs (WWTP-A and WWTP-B) that treat lixiviates from plants recycling the previously separated organic fraction from the municipal solid wastes $[45,46]$ were sampled. In the WWTP-A, the Anaerobic Digestion (AD) is carried out by means of a high solids system (dry process, i.e., solids concentration higher than $15 \%$ ) and in the WWTP-B, the AD is carried out by means of a low solids system (wet-process, i.e., solids concentration that is lower than 10\%). Both WWTPs were designed to eliminate organic matter and nitrogen [46].

For both plants, the MBR configuration was the same, i.e., membranes were external and mixed liquor was pumped from the biological reactor to the UF module. The membranes used in the plants were multichannel tubular and the installed active surface was $127 \mathrm{~m}^{2}$ (WWTP-A) and $72 \mathrm{~m}^{2}$ (WWTP-B). Biological reactors consisted of one anoxic tank, two aerobic tanks, and a final tank that can be operated aerobically or anoxically, depending on the nitrogen removal efficiencies [46].

\subsection{Sampling and Strain Isolation}

Five samples were collected, between September 2014 and July 2015, from the final tank of the biological reactor of both WWTPs and were maintained at $4{ }^{\circ} \mathrm{C}$ until they were processed. For bacterial isolation, aliquots of $1 \mathrm{~mL}$ were taken from the samples, and 10-fold dilutions were made serially to a final dilution of $10^{-5}$. After that, $100 \mu \mathrm{L}$ aliquots were plated onto four different mediums: Luria-Bertani medium (LB); Reasoner's 2A Agar (R2A); Violet Red Bile Glucose Agar (VRBG) for the detection and count of the enterobacteria and Pseudomonas Selective Isolation Agar (PSIA). Two plates of each dilution were incubated at $28^{\circ} \mathrm{C}$ for $1-2$ days (LB and R2A medium); for PSIA and VRBG medium, two plates of each dilution were incubated at $37^{\circ} \mathrm{C}$ for $4-5$ days. For the estimation of CFUs, the plates with 30-300 colonies were selected. For strain isolation, different macroscopic characteristics, such as colony morphology, color, or roughness were used. After several rounds of isolation, pure cultures were subjected to Gram staining. The obtained isolates were maintained on LB medium at $4{ }^{\circ} \mathrm{C}$.

\subsection{Identification of Isolates}

Bacterial isolates were identified by the sequence analysis of the 16S rRNA gene. Genomic DNA from the different isolates was extracted (UltraClean ${ }^{\circledR}$ Microbial DNA Isolation Kit-MO BIO Laboratories, Inc., Carlsbad, CA, USA) and bacterial 16S rRNA gene was amplified using forward Y1 primer ( $5^{\prime}$-TGG CTC AGA ACG AAC GCT GGC GGC-3') and reverse Y2 primer (5'-CCC ACT GCT GCC TCC CGT AGG AGT-3') to amplify a 348-bp fragment from the $16 \mathrm{~S}$ rRNA gene [47]. PCRs were conducted in a $50 \mu \mathrm{L}$ reaction volume in thin-walled $0.2 \mathrm{~mL}$ tubes. Briefly, $16 \mu \mathrm{L}$ of DNA template were added to a $25 \mu \mathrm{L}$ master reaction mixture (Ready-Mix ${ }^{\mathrm{TM}}$ Taq PCR Reaction Mix, Sigma-Aldrich, Madrid, Spain), $2 \mu \mathrm{L}$ of $\mathrm{Y} 1(50 \mu \mathrm{M})$ and $2 \mu \mathrm{L}$ of $\mathrm{Y} 2(50 \mu \mathrm{M})$ primers, and $5 \mu \mathrm{L}$ of sterile distilled water. PCRs were carried out under the following standard conditions: initial denaturation at $95^{\circ} \mathrm{C}$ for $10 \mathrm{~min}$, followed by 30 cycles that were consisting of denaturation at $95^{\circ} \mathrm{C}$ for $45 \mathrm{~s}$, annealing at $58{ }^{\circ} \mathrm{C}$ for $1 \mathrm{~min}$, and extension at $72{ }^{\circ} \mathrm{C}$ for $45 \mathrm{~s}$, followed by a final extension at $72{ }^{\circ} \mathrm{C}$ for $10 \mathrm{~min}$. The PCR-amplified fragments were analyzed by electrophoresis in $1.2 \%$ of agarose in TAE buffer and staining with GelRed ${ }^{\circledR}$ (Biotium, Fremont, CA, USA) The amplification efficiency was analyzed under UV light, and images were taken with a digital camera. The amplified fragments were purified with the UltraClean ${ }^{\mathrm{TM}}$ PCR Clean-Up PCR purification kit (MO BIO Laboratories, Inc., Carlsbad, CA, USA) according to the manufacturer's protocol. A total of twenty-one 16S rRNA gene sequences were identified and were compared by BLAST-search (GenBank; http:/ / www.ncbi.nlm.nih.gov). 16S rRNA gene sequences were aligned using CLUSTAL W2 [48]. The sequences were deposited in GenBank under the accession numbers: KU897070 to KU897089 and KU597170 (Rhodococcus ruber 54B). 


\subsection{Detection of AHL Production by Agar Plate Assay}

A screening was done to detect AHL production by Gram-negative isolated strains. For this assay, two reporter strains were used: Chromobacterium violaceum CV026 [49,50] and Agrobacterium tumefaciens NT1 [51].

The strains were streaked in parallel to the biosensor strains on LB agar plates for $C$. violaceum CV026, and LB agar plates with $60 \mu \mathrm{g} / \mathrm{mL}$ of X-gal (5-bromo-4-chloro-3-indolyl- $\beta$-D-galactopyranoside) for A. tumefaciens NT1. The most active agonist AHL for C. violaceum CV026 is C6-AHL; other AHLs that induce the production of violacein include C6-3-oxo-AHL and C8-AHL, C8-3-oxo-AHL and C4-AHL reasonably well. A. tumefaciens NT1 can produce a blue color from the hydrolysis of X-Gal by the $\beta$-galactosidase activity in response to 3-oxo-substituted AHL-derivatives with acyl chain lengths from 4 to 12 carbons and also 3-unsubstituted AHLs, with the exception of C4-AHL. This sensor can also detect 3-hydroxy derivatives, more precisely, C6-3-hydroxy-AHL, C8-3-hydroxy-AHL, and C10-3-hydroxy-AHL [52]. Plates were incubated at $30{ }^{\circ} \mathrm{C}$ for $48 \mathrm{~h}$.

\subsection{Surface Adherence Capability of AHL Producers}

Gram-negative strains were cultured in liquid LB medium overnight at $28^{\circ} \mathrm{C}(120 \mathrm{rpm})$ and were then diluted to reach an OD600nm of 0.1 in the same medium. Subsequently, $100 \mu \mathrm{L}$ of each diluted culture were pipetted into each one of eight wells of a sterile non-treated polyethylene 96-well microtiter plate (Corning ${ }^{\circledR}$ Costar $^{\circledR}$ culture plates, Sigma-Aldrich). Sterile LB medium was used as a negative control. Microtiter plates were prepared in duplicate and incubated at $28^{\circ} \mathrm{C}(120 \mathrm{rpm}, 24 \mathrm{~h})$. The adherence capabilities were quantified according to the crystal violet method that was described by Merritt et al. (2005) [53]. Absorbance was measured at $590 \mathrm{~nm}$ at room temperature using an iEMS Reader MF (Labsystems, Helsinki, Finland). This assay was carried out in duplicate and eight readings were recorded for each strain. According to Stepanovic et al. (2000) [54], the strains were classified by their adherence capabilities in: (1) non-adherent (Abs < Abscontrol); (2) weakly adherent (Abscontrol $<$ Abs $<2 \times$ Abscontrol); (3) moderately adherent $(2 \times$ Abscontrol $<$ Abs $<4 \times$ Abscontrol); and, (4) strongly adherent (Abs $>4 \times$ Abscontrol).

\subsection{Detection of Quorum Quenching Activity by the Agar Plate Assay}

Three different AHL (Sigma-Aldrich, Spain) were used: C6-HSL ( $N$-hexanoyl-DL-homoserine lactone), C8-HSL (N-octanoyl-DL-homoserine lactone), and C12-HSL ( $N$-dodecanoyl-DL-homoserine lactone). To detect $Q Q$ activity of the isolated Gram-positive bacteria, both reporter strains mentioned previously and Aeromonas hydrophila (strain E2MB52) as negative control, were grown in $4 \mathrm{~mL}$ of LB broth at $28{ }^{\circ} \mathrm{C}$ and $120 \mathrm{rpm}$. After $24 \mathrm{~h}$, the strains were diluted to an OD600 $\mathrm{nm}$ of 0.5 in the same medium. Subsequently, $5 \mu \mathrm{L}$ of each AHL stock solution were added to Gram-positive cultures to achieve a final concentration of $0.5 \mu \mathrm{g} \mathrm{mL}-1$, and were incubated at $28^{\circ} \mathrm{C}$ and $120 \mathrm{rpm}$. After $24 \mathrm{~h}$, $50 \mu \mathrm{L}$ of the supernatants were spotted in duplicate in wells that were made on LB agar plates overlaid with $5 \mathrm{~mL}$ of overnight cultures of $C$. violaceum CV026 (or A. tumefaciens NT1) in soft LB ( $0.8 \%$ agar). Fifty $\mu \mathrm{L}$ of $A$. hydrophila supernatant and $50 \mu \mathrm{L}$ of sterile LB that was supplemented with C6-HSL, C8-HSL, or C12-HSL were used as negative controls in all of the plates. Fifty $\mu \mathrm{L}$ of sterile LB were used as positive control.

\subsection{QQ Strains Addition to Mixed Liquors and Monospecific Bacterial Biofilms}

To perform these tests, strains with QQ activity were added to mixed liquors of WWTP-A and WWTP-B $\left(\mathrm{ML}_{\mathrm{A}}\right.$ and $\mathrm{ML}_{\mathrm{B}}$ - both diluted to $\left.10^{-1}\right)$ and P. aeruginosa (QS1) cultures. These assays were performed using both, cell cultures and culture supernatants. All of the strains were grown overnight at $28{ }^{\circ} \mathrm{C}$ and $120 \mathrm{rpm}$ in sterile tubes containing liquid LB medium and then diluted to reach an OD600nm of 0.1 in the same medium. Subsequently, $50 \mu \mathrm{L}$ of QQ strains and $50 \mu \mathrm{L}$ of AHL producers were pipetted into each one of eight wells of a sterile non-treated polyethylene 96-well microtiter plate 
(Corning ${ }^{\circledR}$ Costar $^{\circledR}$ culture plates, Sigma-Aldrich). One hundred $\mu \mathrm{L}$ of sterile liquid medium were used as a negative control and $100 \mu \mathrm{L}$ of the AHL producer were used as a positive control. Then, microtiter plates were prepared in duplicate and were incubated at $28{ }^{\circ} \mathrm{C}$ and $120 \mathrm{rpm}$ during $24 \mathrm{~h}$ and adherence capabilities were quantified using the crystal violet procedure that is cited above.

\subsection{Effect of $Q Q$ Strains on Ultrafiltration Fluxes}

Ultrafiltration (UF) tests were performed in an automated UF laboratory plant (Figure S1) that was equipped with elements for the regulation of the cross-flow velocity (CFV), transmembrane pressure (TMP), and temperature. The fouling tests were carried out at the following operation conditions: 1 bar of TMP, $25^{\circ} \mathrm{C}$, and $2 \mathrm{~m} \mathrm{~s}^{-1}$ of CFV. The membrane that was used in every test was a $150 \mathrm{kDa}$ cut-off hydrophilic polyethersulfone membrane (Nadir UH150, Microdyn Nadir, Germany). New membranes were used for each experiment and its initial permeability was measured using deionized water before each UF test with mixed liquor. The duration of each test was $3 \mathrm{~h}$, time required to reach the steady state. Permeate and retentate were recirculated into the feed tank. The permeate flux was monitored with an electronic weighing scale (KERN KB 2400-2N, 0.01 g accuracy, Kern \& Sohn GmbH, Balingen, Germany) and the collected data were recorded, every $15 \mathrm{~s}$, with data acquisition software (Balance Connection SCD-4.0, Kern ${ }^{\circledR}$, Kern \& Sohn GmbH, Balingen, Germany).

Two types of tests were performed. First, an assay that was based on a direct inoculation of strains with positive $Q Q$, which had been selected as best candidates in the previous experiments, and, second, an assay that is based on the encapsulation with alginate of the QQ strains [24] to achieve the immobilization of cells while maintaining the desired catalytic activity and cellular viability. The total volume for each assay was approximately 3.25 L:1 L of mixed liquor from each WWTP, $2 \mathrm{~L}$ of purified water, and $250 \mathrm{~mL}$ of bacterial culture in stationary phase (applied directly or entrapped in alginate spheres). For bacteria entrapment exponentially growing bacterial cells were suspended in $2 \%$ sodium alginate $(v / v)$. This bacterial-alginate mixture was dripped from a height of $10 \mathrm{~cm}$ into $100 \mathrm{~mL}$ of crosslinking solution $\left(0.05 \mathrm{M}\right.$ of $\left.\mathrm{CaCl}_{2}\right)$. The gel formation was achieved with a syringe at room temperature as soon as the sodium alginate drops come in direct contact with the calcium solution. The beads should be fully formed in $30 \mathrm{~min}$. Relatively small $(3-4 \mathrm{~mm})$ alginate beads were preferred to minimize the mass transfer resistance.

\subsection{Quantification of Enzymatic Activities}

AHL degradation by lactonases was determined using high-pressure liquid chromatography-mass spectrometry (HPLC-MS). One mL sample, obtained from a $24 \mathrm{~h} 15 \mathrm{~mL} \mathrm{LB}$ culture of the selected strains, was centrifuged at 10,000 rpm for $10 \mathrm{~min}$ to separate the cells from the culture media. Supernatants were removed and pellets were resuspended with $1 \mathrm{~mL}$ of PBS pH 6.5, mixed with $40 \mu \mathrm{L}$ of $\mathrm{C} 6$ or C12-HSL $\left(2 \mu \mathrm{g} \mathrm{mL}^{-1}\right)$, and incubated for $24 \mathrm{~h}$ at $22{ }^{\circ} \mathrm{C}$ and $150 \mathrm{rpm}$ rotary shaking. $500 \mu \mathrm{L}$ of the mixture were directly extracted twice with an equal volume of ethyl acetate, evaporated under nitrogen flux at $50{ }^{\circ} \mathrm{C}$, and resuspended in $200 \mu \mathrm{L}$ acetonitrile to quantify the remaining AHLs. The remaining $500 \mu \mathrm{L}$ of the mixture were acidified with $\mathrm{HCl} 5 \mathrm{M}$ to $\mathrm{pH} 2.0$ and incubated for $24 \mathrm{~h}$ at $22{ }^{\circ} \mathrm{C}$ before extraction in order to facilitate the recovery of the AHL activity derived from the hydrolysis of the lactone ring derived from the action of lactonases. Each AHL dissolved in PBS at the same concentration was used as control [55,56]. HPLC-MS analyses were performed with a HPLC 1100 series (Agilent), equipped with a C8 precolumn $2.1 \times 12.5 \mathrm{~mm}(5 \mu \mathrm{m}$ particle size) and a Zorbax Eclipse XDB-C18 $150 \times 4.6 \mathrm{~mm}$ column ( $5 \mu \mathrm{m}$ particle size) [55]. The mobile phase was composed of $0.1 \%$ formic acid in water (A) and $0.1 \%$ formic acid in acetonitrile (B) [57]. The elution conditions were described by Romero et al. (2011) [55]. MS experiments were conducted on an API4000 triple-quadrupole linear ion trap mass spectrometer (Applied Biosystem, Foster City, CA, USA) equipped with a TurboIon source using positive ion electrospray, multiple reaction monitoring (MRM) mode [55,56,58]. The MRM signals were used to generate relative quantification information by comparison with a calibration 
curve that was constructed for molecular ion abundance, using each of the appropriate AHL synthetic standards [59].

PVA activity was assayed by the PDAB method, which is based on the formation of a Schiff base when 6-aminopenicillanic acid has reacted with $p$-dimethylamino benzaldehyde (PDAB) [60]. Cultures were grown in $50 \mathrm{~mL}$ Falcon ${ }^{\circledR}$ flasks (Thermo Fisher Scientific, Majadahonda, Madrid) containing $15 \mathrm{~mL}$ of LB medium $\left(24 \mathrm{~h}\right.$ at $28{ }^{\circ} \mathrm{C}$ and $\left.120 \mathrm{rpm}\right)$. After centrifugation $(9000 \times \mathrm{g})$, the cells were removed. The proteins of the supernatant were precipitated with $70 \%(v / v)$ ethanol, and, after centrifugation at $4000 \times g$ for $30 \mathrm{~min}$, the precipitate was resuspended in $135 \mu \mathrm{L} 1 \mathrm{M}$ phosphate buffer ( $\mathrm{pH}$ 8). Then, the PVA acylase activity was determined at $40{ }^{\circ} \mathrm{C}$ for $60 \mathrm{~min}$. Reaction mixture contained $150 \mu \mathrm{L}$ of penicillin $\mathrm{V}\left(45 \mathrm{mg} \mathrm{mL}^{-1}\right), 135 \mu \mathrm{L}$ of resuspended supernatant, and $15 \mu \mathrm{L}$ of $1 \mathrm{M}$ potassium phosphate buffer ( $\mathrm{pH} 8$ ). To stop the reaction, $900 \mu \mathrm{L}$ of $20 \%$ acetic acid water solution were added in an ice bath. Samples were centrifuged $(2 \mathrm{~min}, 9000 \times g)$ and $250 \mu \mathrm{L}$ of the supernatant transferred to $100 \mu \mathrm{L}$ of PDAB $(0.5 \% w / v$ in methanol). Then, the absorbance at $405 \mathrm{~nm}$ was recorded for the determination of 6-APA concentration (Balasingham et al., 1972). One unit of enzyme activity was defined as the amount of enzyme that is required to produce $1 \mu \mathrm{mol} 6-\mathrm{APA} / \mathrm{min}$ at $\mathrm{pH} 8$ and $40{ }^{\circ} \mathrm{C}[61]$.

\section{Results}

\subsection{Identification and Characterization of Bacterial Isolates}

A total of 99 bacterial strains (48 strains from WWTP-A and 51 from WWTP-B) were isolated from MBR activated sludge, with cellular densities that were ranging from $4.5 \times 10^{5} \mathrm{CFU} \mathrm{mL} \mathrm{mL}^{-1}$ to $2.95 \times 10^{7} \mathrm{CFU} \mathrm{mL}^{-1}$, using culture-dependent techniques on LB, R2A, VRBG, and PSIA media. Seventy-one strains were Gram-positive and the other 28 strains were Gram-negative. Comparison of the nearly complete 16S rRNA nucleotide sequences confirmed that the isolates belong to four different genera Bacillus, Gordonia, Pseudomonas, and Aeromonas, with a predominance of Bacillus cereus and Pseudomonas aeruginosa in all cases, similarity values among the isolated strains and the closest relative strains were between the $99 \%$ and the 100\% (Table S1). A Rhodococcus strain from our laboratory collection was also included in the research (Rhodococcus ruber 54B-accession number KU597170) due to the reported ability of Rhodococcus to prevent biofouling in MBR [23,24,26,62].

\subsection{AHL Producers and Potential Adherence to Surfaces}

Twenty-eight Gram-negative strains were tested against the reporter strains (C. violaceum CV026 and A. tumefaciens NT1). C. violaceum CV026 responded positively only to A. hydrophila E2MB52, indicating the production by this strain of short or medium-chain AHLs. A. tumefaciens NT1 responded to five bacterial isolates (A. hydrophila E2MB52; P. pseudoalcaligenes E2MB82; Thauera butanivorans E2DN83; P. aeruginosa E2MBUPVDN12; and, E2MBUPVDN20), suggesting that those strains produce medium or long-chain AHLs.

The five AHL producers, the $5.1 \%$ of the total isolates (17.8\% of the Gram negatives), were used to test their adherence and subsequent ability to form biofilms on polyethylene surfaces. All of them reached OD $590 \mathrm{~nm}$ above the average value of the control (sterile medium) at $24 \mathrm{~h}$ of incubation, although the strain E2MB82, which is a P. pseudoalcaligenes, clearly recorded the highest absorbance values (Figure S2), indicating high effectiveness in surface colonization (Table 1). 
Table 1. Relative estimation of $N$-acyl homoserine lactones (AHL) production assessed by biosensors among Gram negative isolates and the adherence capability of AHL producers.

\begin{tabular}{lccc}
\hline Bacterial Strains & C. violaceum CV026 & A. tumefaciens NT1 & Adherence Capability \\
\hline Aeromonas hydrophila E2MB52 & Strong & Moderate & Moderate \\
Pseudomonas pseudoalcaligenes E2MB82 & Non-detected & Strong & Strong \\
Thauera butanivorans E2DN83 & Non-detected & Moderate & Strong \\
Pseudomonas aeruginosa E2MBUPVDN12 & Non-detected & Moderate & Strong \\
Pseudomonas aeruginosa E2MBUPVDN20 & Non-detected & Moderate & Strong \\
\hline
\end{tabular}

\subsection{Inhibition of $A H L$ and $Q Q$ Assays}

Fifteen strains, approximately $15 \%$ of isolates ( $21.1 \%$ of the Gram-positive strains), were able to inhibit the C6-HSL, C8-HSL and C12-HSL that were exogenously added, indicating their probable QQ activity (Table 2, Figure S3). Among these strains, 46.6\% (seven strains) were active against the three AHLs that were analyzed and the remaining $53.4 \%$ (eight strains) were positive for two AHLs.

Table 2. Detection of Quorum Quenching (QQ) activity with the AHL biosensors Chromobacterium violaceum CV026 and Agrobacterium tumefaciens NT1. QQ-positive strains degraded AHLs (30 mM C6-HSL; $20 \mathrm{mM} \mathrm{C8-HSL;} 30 \mathrm{mM} \mathrm{C12-HSL)} \mathrm{after} 24 \mathrm{~h}$, inhibiting violacein production and/or $\mathrm{X}-\mathrm{Gal}$ hydrolysis.

\begin{tabular}{lcccc}
\hline WWTP & Bacterial Strains & C6-HSL & C8-HSL & C12-HSL \\
\hline WWTPA & Bacillus cereus E1DN3 & +1 & + & - \\
WWTPA & Bacillus subtilis E1DN6 & -2 & + & + \\
WWTPA & Bacillus sp. E1DN7 & + & + & + \\
WWTPA & Gordonia paraffinivorans E1N2.12 & - & + & + \\
WWTPA & Bacillus cereus E1DN27 & - & + & + \\
WWTP B & Bacillus cereus E2N2.8 & + & + & + \\
WWTP B & Bacillus thuringiensis E2DN25 & + & + & + \\
WWTP B & Bacillus sp. E2DN30 & - & + & + \\
WWTP B & Bacillus cereus E2DN35 & + & + & + \\
WWTP B & Bacillus cereus E2DN36 & + & + & + \\
WWTP B & Bacillus cereus E2AL40 & + & + & + \\
WWTP B & Bacillus cereus E2AL41 & + & + & + \\
WWTP B & Bacillus thuringiensis E2MB58 & - & + & + \\
WWTP B & Bacillus subtilis E2MB60 & - & + & + \\
WWTP B & Bacillus cereus E2DN70 & + & + & + \\
\hline
\end{tabular}

${ }^{1}$ (+; degraded), ${ }^{2}$ (-; non-degraded).

Based on the previous results, 11 QQ strains belonging to different species and that were able to inactivate long- and medium-chain AHLs were selected to test their effectiveness in reducing biofilm formation using both real wastewater [mixed liquor $\mathrm{A}\left(\mathrm{ML}_{\mathrm{A}}\right)$ and mixed liquor $\mathrm{B}\left(\mathrm{ML}_{\mathrm{B}}\right)$ ] and monospecific biofilm of a wastewater-relevant strain of P. aeruginosa. As shown in Figure 1, the highest inhibition was obtained through the exposition of $\mathrm{ML}_{\mathrm{A}}$ to the quencher cultures with values that were up to the $60 \%$ in the case of the strains E2MB60 (73.38\%), E2N2.8 (71.31\%), and E2DN25 (64.01\%). $\mathrm{ML}_{\mathrm{B}}$ biofilm reduction showed much lower values than the previous case. Interestingly, better results were assessed with indigenous QQ bacteria than with strains pertaining to the well-known QQ genus Rhodococcus, although, regarding the inhibition of monospecific P. aeruginosa QS1 (strong producer of long chain AHLs, Table 1) biofilm, only with the use of the strains R. ruber 54B and B. subtilis E2MB60 (able to degrade only long-chain AHLs, Table 2), were noteworthy results obtained.

At this point of our experimental work, the strains B. subtilis E2MB60, B. cereus E2N2.8, B. thuringiensis E2DN25, and R. ruber 54B, were selected to study the relationship between QQ activity and biofouling in a UF laboratory plant (see Section 2.8. of Material and Methods section). The tested 
strains were applied directly or were entrapped in alginate spheres. Figure 2 indicates a substantial increase of permeate flux when the mixed-liquor from WWTP-A $\left(\mathrm{ML}_{\mathrm{A}}\right)$ was employed in the presence of the entrapped $R$. ruber $54 \mathrm{~B}$, suggesting that the immobilization material used might protect this strain from wastewater composition permitting its anti-biofouling ability. Moreover, the results that were obtained with the direct addition of the strain E2MB60 (also to some extent with the E2N2.8), confirmed both, the survival capacity of this specie and its ability as quorum quencher under those environmental conditions. Referring to mixed liquor of WWTP-B $\left(\mathrm{ML}_{\mathrm{B}}\right)$, no substantial changes were observed in permeate fluxes when values of control and quenchers presence were compared.

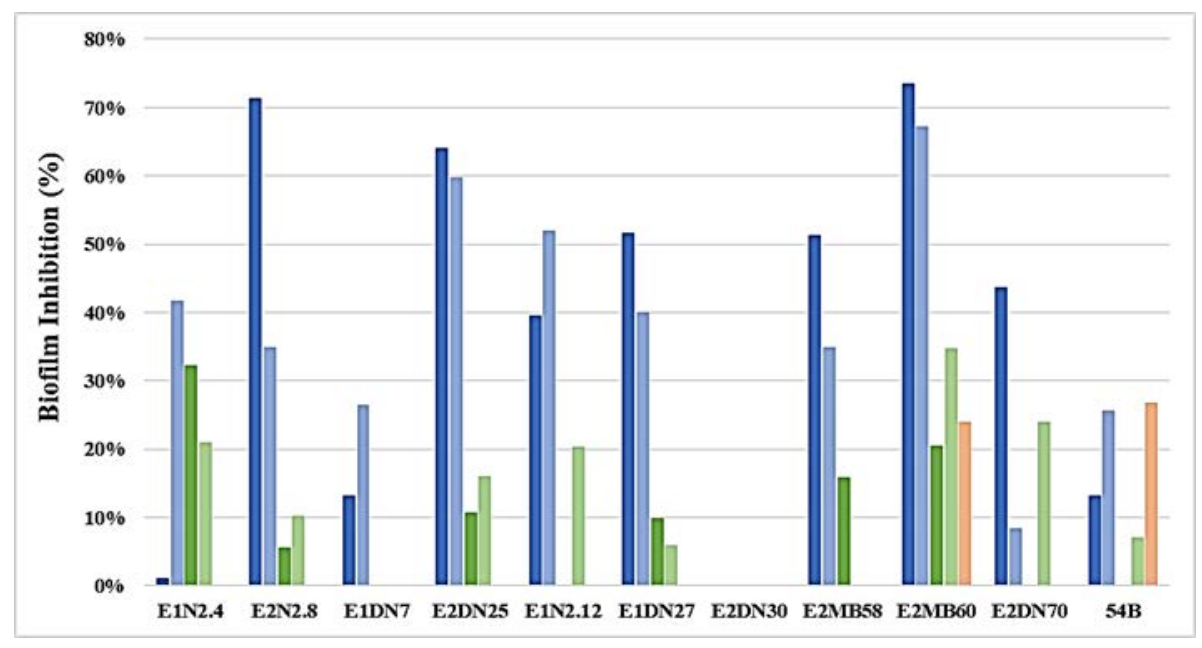

Figure 1. Inhibition of biofilm formation after $24 \mathrm{~h}$ incubation in the presence of the eleven strains selected due to their $Q Q$ activity. Mixed liquor $A\left(\mathrm{ML}_{\mathrm{A}}\right)$, mixed liquor $\mathrm{B}\left(\mathrm{ML}_{\mathrm{B}}\right)$, and a pure culture of Pseudomonas aeruginosa (QS1) were used for biofilm development (meaning de $100 \%$ value) and then exposed to the strains E1N2.4, E2N2.8, E1DN7, E2DN25, E1N2.12, E1DN27, E2DN30, E2MB58, E2MB60, E2DN70, and 54B (cell cultures and cultures supernatants). QQ cell cultures in $\mathrm{ML}_{\mathrm{A}}$ (blue bars), $\mathrm{QQ}$ supernatants in $\mathrm{ML}_{\mathrm{A}}$ (light blue bars), QQ cell cultures in $\mathrm{ML}_{\mathrm{B}}$ (green bars), QQ supernatants in $\mathrm{ML}_{\mathrm{B}}$ (light green bars), and QQ supernatants in P. aeruginosa cultures (orange bars) were tested.

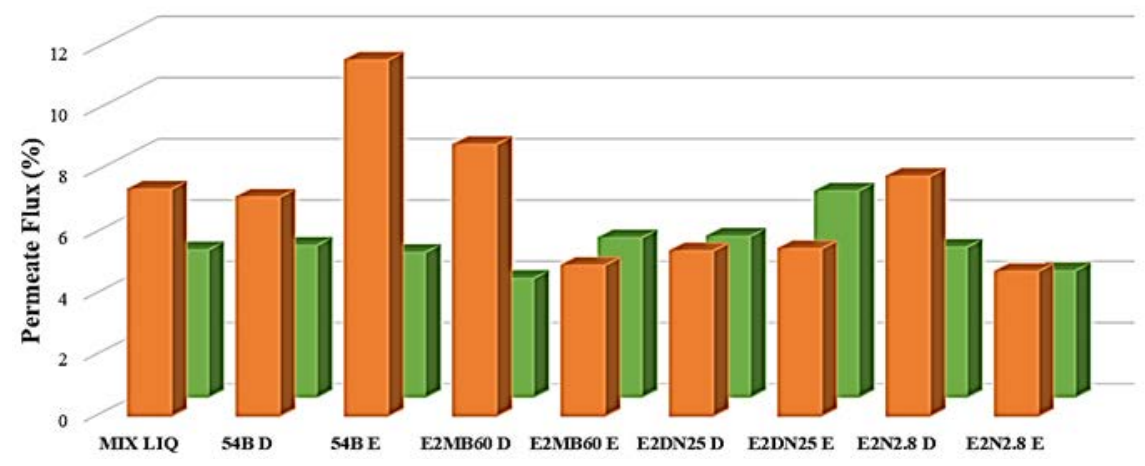

Figure 2. Changes in permeate flux through an ultrafiltration membrane after treatment of water samples with the selected strains. Water samples, from WWTP (MIX LIQ orange) and WWTP $_{\mathrm{B}}$ (MIX LIQ green), were inoculated with the bacterial strains 54B, E2MB60, E2DN25, and E2N2.8 using two methods: direct inoculation of the strains (D) and alginate-entrapped cells (E). Permeate flux was appreciably increased when $\mathrm{ML}_{\mathrm{A}}$ was treated with strains 54B (E), E2MB60 (D), and E2N2.8 (D). 


\subsection{Enzymatic Activities of Selected QQ Strains}

\subsubsection{Lactonase Activity}

The capacity of the selected strains to hydrolyze C6- and C12-HSL was confirmed by HPLC-MS. As expected, all four strains were able to reduce the concentration of the C12-HSL, showing more than $90 \%$ of QQ activity. This capacity was lower against C6-HSL (Figure 3). The spontaneous lactonization of the AHLs due to high $\mathrm{pH}$ was not taken into account since the $\mathrm{pH}$ of cultures was lower than seven in all cases. To verify that the QQ activity was due to the action of a lactonase enzyme, cultures containing C6-HSL and C12-HSL were acidified. This allows for the lactone ring to reassemble if it has been previously opened by a lactonase $[58,63]$. The results showed that the C6-HSL degradation was due to the activity of a lactonase enzyme because the AHL values detected were higher than the non-acidified samples; however, this fact did not occur in the C12-HSL samples, suggesting other enzymatic activity than a lactonase or to be further degraded by a different enzyme after the addition of lactonase, precluding its detection.

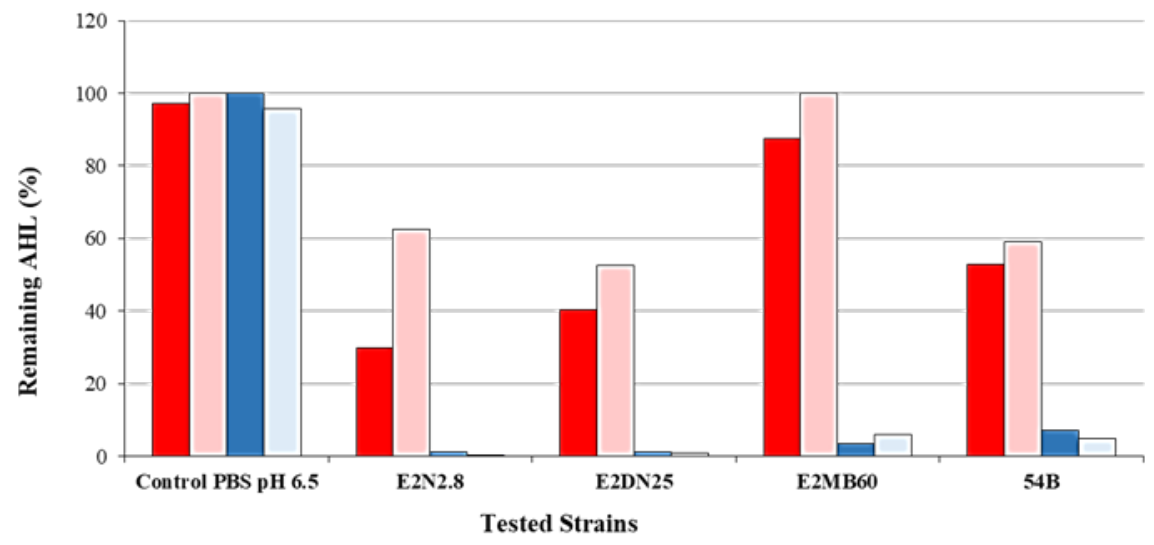

Figure 3. High-pressure liquid chromatography-mass spectrometry (HPLC-MS) analysis of the remaining C6-HSL and C12-HSL after $24 \mathrm{~h}$ of incubation with the four selected strains. In order to allow for the recovery of the lactone ring after lactonolysis, culture media containing C6-HSL or C12-HSL were acidified to pH 2.0. C6-HSL (red bars), C6-HSL acidified (light red bars), C12-HSL (blue bars), and C12-HSL acidified (light blue bars). Strains tested were as follows: B. cereus E2N2.8, B. thuringiensis E2DN25, B. subtilis E2MB60, and R. ruber 54B.

\subsubsection{Acylase Activity}

Penicillin acylases bear the ability to cleave penicillin, and, due to wide substrate specificity, also bacterial AHLs [60,64] Penicillin V acylase (PVA) hydrolyzes penicillin V producing 6-aminopenicillanic acid (6-APA) and phenoxyacetic acid $[61,65,66]$, and this mechanism has been used in the present study to determine the presence of acylase activities in the four selected bacterial isolates. As can be seen in Figure 4, all strains that were produced low levels of PVA when grown in LB medium, and, according to the results presented in the same figure, there were no important differences in PVA activity among the selected strains and controls, suggesting that the QQ activity that was ascribed to these strains were probably not due to an acylase activity. It must be considered, for a feasible comparison, that some strains of Streptomyces lavendulae $[60,61]$ produce acylase activities in several orders of magnitude higher than the present strains (data not shown). 


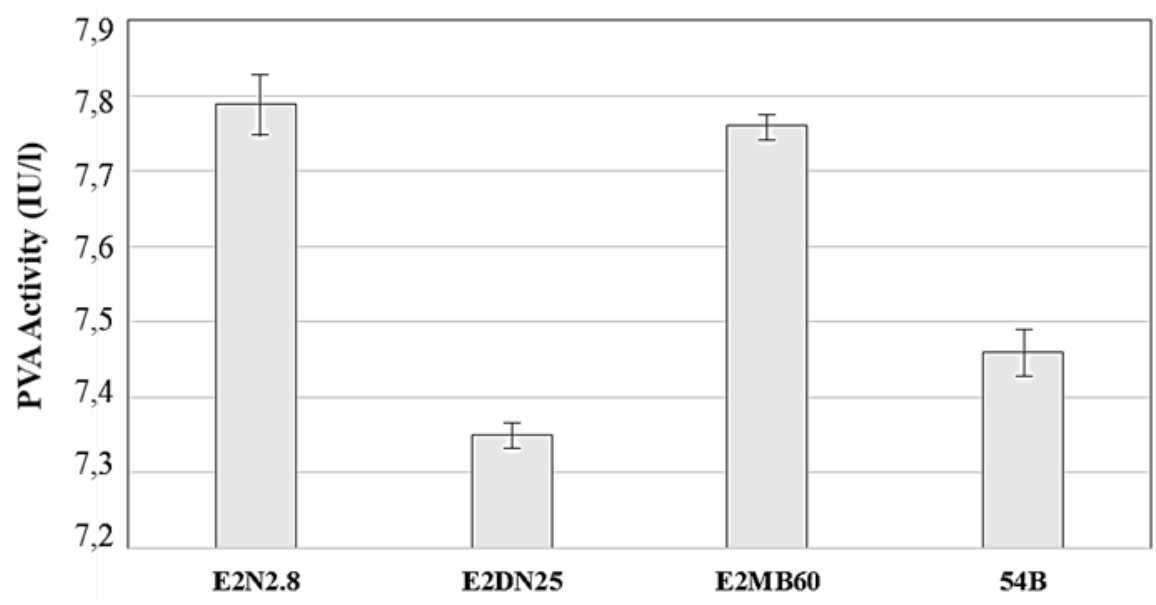

Figure 4. Amount of penicillin V acylase (PVA) activity detected in the supernatants of B. cereus E2N2.8, B. thuringiensis E2DN25, B. subtilis E2MB60, and R. ruber 54B. Error bars indicate the standard deviation.

\section{Discussion}

According to recent publications $[19,62,67-70]$, QS and QQ processes are very common in natural and anthropic environments, even WWTP. This work shows, in agreement with other studies in WWTP (aerobic granules [71]), the presence in MBR activated sludge of bacterial AHL producers, quenchers, and isolates, with no AHL producing or quenching activity. Among the five AHL-producing isolates (5.1\% of the total), three belonged to the Pseudomonas genus (two were P. aeruginosa species), and the other was $A$. hydrophila, both have been described as key species that are involved in the process of biofilm formation, which causes membrane biofouling in MBR systems [44].

It is remarkable the predominance of AHL quenchers (15) over AHL producers (5). However, this result should be interpreted with caution since it could be a bias derived from the use of culture conditions not resembling the natural environment. A recent study on four different Escherichia coli strains showed that the $47 \%$ of the variance in expression levels is primarily dependent on the environment (medium-dependent genes) [72]. Even, growing the bacteria in shaken cultures or static conditions was reported to effect on QS AHL profile [70]. Furthermore, the percentage of $15.1 \%$ of strains with QQ activity is a high percentage when we compare these results with similar studies in environments, such as soils, where percentages vary among the $2 \%$ and the $4.8 \%$ [38-40], but are comparable to the marine environment, where the percentage was about the $14.4 \%$ [55]. The isolation protocol that is employed seems to be decisive and might explain these data, as we decided to use a similar procedure to the one proposed by Romero et al. (2011) [55]. In other studies, AHL-degrading bacteria were isolated following an enrichment procedure based on the utilization of AHLs as sole source of carbon and nitrogen, but the number of isolated quorum quenching bacteria was lower $[29,35,73,74]$.

Among the 15 QQ isolates, 13 of them belonged to the species B. cereus, B. subtilis, and B. thuringiensis, which have been described previously as capable of degrading AHL by the action of a specific gene, aiiA-Autoinducer Inactivator A, encoding a lactonase enzyme that inactivates the AHL by hydrolyzing the core lactone ring [38-42]. Besides, the isolate 54B (R. ruber) from the bacterial lab collection was included in our experimental work since the research on Rhodococcus genus and specifically the species R. erythropolis, R. ruber, or R. qingshengii have demonstrated their ability to degrade AHLs and to inhibit the formation of biofilm [22,35,36,62,74,75]. In fact, it has been also reported that one strain of Rhodococcus (Rhodococcus sp. BH4-99\% identity with R. erythropolis W2) is in effect able to control biofouling in MBR [23,24,26,62], and our strain showed its effectiveness against this problem too. With this aim, we highlight three other adequate candidates for future studies in order to overcome laboratory limitations and be used in pilot-scale QQ-MBR: B. subtilis E2MB60, B. cereus E2N2.8, and B. thuringiensis E2DN25. First, it should be noted that results obtained 
from biofilm formation tests using those quorum quenchers and the mixed liquors of the wastewater plants were optimistic although a more adequate inoculum of the AHL-degrading strains should be considered. As for the differences that are related to the microbial mixed liquor adherence, the reductions by these species in $M L_{A}$ were higher than in $M L_{B}$. This fact could be explained by the contribution of chemical in $\mathrm{ML}_{\mathrm{B}}$ (data not shown).

Second, the increase of membrane permeability in an ultrafiltration lab-scale assay while using those strains and the mixed liquor of WWTPs. This assay, in an attempt to indirectly determine whether bacteria quenchers could diminish biofouling, showed an evident reduction of the biofouling that is produced on the membrane with water samples from $\mathrm{WWTP}_{\mathrm{A}}$, although with water samples from $\mathrm{WWTP}_{\mathrm{B}}$, there was not almost any flux increase in the presence of $\mathrm{QQ}$ bacteria, which could be due to the high concentrations of polyelectrolytes that is used in $\mathrm{WWTP}_{\mathrm{B}}$, and so on not related to biofouling.

Last, the confirmation of enzymatic QQ activity by the selected isolates using both bacterial biosensors and HPLC-MS techniques. The results showed that the selected strains have the capacity to degrade medium- and long-chain AHLs. Moreover, all of the strains showed that enzymatic activity might be due to a lactonase enzyme because there was a partial recovery of the C6-HSL by posterior acidification, although in the case of C12-HSL, where the recovery of the lactone ring did not occur, the enzymatic activity may be due to an enzyme other than lactonase.

To clarify this aspect, penicillin V acylase (PVA) activity was investigated. According to Mukherji et al. (2014) [64], these enzymes may have the ability to cleave medium chain length AHLs with great efficiency. Although the experimental values obtained demonstrated the presence of PVA, they were low although being comparable to those that were obtained by Rolinson et al. (1961) [76]. According to Torres et al. (1999) [61], the influence of the culture medium plays an important role in the production of this enzyme; therefore, further research will be done in this sense. This is indicated since a recent study [77] shows that PVAs can decrease the biofilm formation of P. aeruginosa, however, the low values of activity that were obtained in our study could not be sufficient to inhibit the biofilm formation. In the particular case of B. subtilis E2MB60, our good results using this specie could be related to the possible production of subtilosin, a cyclic lantibiotic protein, which has been related to biofilm reduction [78].

\section{Conclusions}

To summarize, this study shows a first approximation for the application of AHL-degrading bacteria to inhibit biofilm formation on membrane bioreactors. Certain strains that were isolated from two MBR wastewater plants treating leachate from municipal solid waste in Spain, showed effectiveness, especially those that were belonging to the genus Bacillus. Several studies have been carried out worldwide on this subject however; this is the first time they were performed in Spain. Further pilot-scale QQ-MBR studies will be done based on direct strain addition and/or the encapsulation with alginate in order to verify their utility to solve biofouling problems, and increase the useful lifespan of the membranes, minimizing operational costs.

Further experiments are warranted to gain a better understanding on the practicality of this technology for biofouling control in membrane systems. Currently, additional studies on the QQ activity exerted by the AHL-degrading enzyme acylase from Actinoplanes utahensis are under development to inhibit biofilm formation by strains of bacteria (mainly Pseudomonas aeruginosa) that were isolated from WWTP. Acylase from A. utahensis has shown a $50-70 \%$ reduction of biofilm formation by P. aeruginosa in both conditions, on solution and attached to borosilicate surfaces.

Supplementary Materials: The following are available online at http:/ /www.mdpi.com/1660-4601/15/5/1019/ s1, Figure S1: Scheme of the automated ultrafiltration laboratory plant used in this study, Figure S2: Adherence capabilities of bacterial isolates after $24 \mathrm{~h}$ of cultivation determined by the crystal violet assay method, Figure S3: Example of detection of QQ activity with the AHL biosensors Chromobacterium violaceum CV026 $(a, b)$ and Agrobacterium tumefaciens NT1 (c), Table S1: Bacterial collection with Genbank accession numbers. 
Author Contributions: S.S., An.S., D.M. and L.A. conceived and designed the experiments; Al.S. and A.M. performed the experiments and analyzed the data, M.A. and J.A.M. contributed with materials and analysis tools; Al.S., L.A., An.S., S.S. and A.M. wrote the paper.

Acknowledgments: The authors want to thank the WWTPs staff for providing the samples. We also thank Dra. Ana Otero (Departamento de Microbiología y Parasitología-CIBUS, Universidade de Santiago de Compostela) for helpful advices and Carlos Carbonell Alcaina (Researcher at Research Institute for Industrial, Radiophysical and Environmental Safety-ISIRYM, Universitat Politècnica de València, Spain) and Rodrigo Velasco Bucheli (Researcher at Department of Biochemistry and Molecular Biology I, Universidad Complutense de Madrid) for technical support. This work was supported by grant from URBASER S.A. (research fund project Biolix 4155519-201/2014) and also by the Spanish Commission of Science and Technology (CTM2016-76491-P). A.M. was supported by a predoctoral fellowship from the Consellería de Cultura, Educación e Ordenación Universitaria, Xunta de Galicia (ED481A-2015/311).

Conflicts of Interest: C.A. and C.G. are employees of R\&D department in Urbaser, S.A.

\section{References}

1. Brown, S.P.; Johnstone, R.A. Cooperation in the dark: Signalling and collective action in quorum-sensing bacteria. Proc. R. Soc. Lond. B Biol. Sci. 2001, 268, 961-965. [CrossRef] [PubMed]

2. Hogan, D.A. Quorum sensing: Alcohols in a social situation. Curr. Biol. 2006, 16, 457-458. [CrossRef] [PubMed]

3. Foster, K.R.; Parkinson, K.; Thompson, C.R.L. What can microbial genetics teach sociobiology? Trends Genet. 2007, 23, 74-80. [CrossRef] [PubMed]

4. Fuqua, W.C.; Winans, S.C.; Greenberg, E.P. Quorum sensing in bacteria-The Luxr-Luxi family of cell density-responsive transcriptional regulators. J. Bacteriol. 1994, 176, 269-275. [CrossRef] [PubMed]

5. Ponnusamy, K.; Paul, D.; Kim, Y.S.; Kweon, J.H. 2(5H)-Furanone: A prospective strategy for biofouling-control in membrane biofilm bacteria by quorum sensing inhibition. Braz. J. Microbiol. 2010, 41, 227-234. [CrossRef] [PubMed]

6. Zhang, W.; Li, C. Exploiting quorum sensing interfering strategies in Gram-negative bacteria for the enhancement of environmental applications. Front. Microbiol. 2016, 6. [CrossRef] [PubMed]

7. LaSarre, B.; Federle, M.J. Exploiting quorum sensing to confuse bacterial pathogens. Microbiol. Mol. Biol. Rev. 2013, 77, 73-111. [CrossRef] [PubMed]

8. Christiaen, S.E.A.; Brackman, G.; Nelis, H.J.; Coenye, T. Isolation and identification of quorum quenching bacteria from environmental samples. J. Microbiol. Methods 2011, 87, 213-219. [CrossRef] [PubMed]

9. Biswa, P.; Doble, M. Production of acylated homoserine lactone by Gram-positive bacteria isolated from marine water. FEMS Microbiol. Lett. 2013, 343, 34-41. [CrossRef] [PubMed]

10. De Decker, S.; Reynaud, Y.; Saulnier, D. First molecular evidence of cross-species induction of metalloprotease gene expression in Vibrio strains pathogenic for Pacific oyster Crassostrea gigas involving a quorum sensing system. Aquaculture 2013, 392, 1-7. [CrossRef]

11. Pande, G.S.J.; Scheie, A.A.; Benneche, T.; Wille, M.; Sorgeloos, P.; Bossier, P.; Defoirdt, T. Quorum sensing-disrupting compounds protect larvae of the giant freshwater prawn Macrobrachium rosenbergii from Vibrio harveyi infection. Aquaculture 2013, 406, 121-124. [CrossRef]

12. Swift, S.; Downie, J.A.; Whitehead, N.A.; Barnard, A.M.L.; Salmond, G.P.C.; Williams, P. Quorum sensing as a population-density-dependent determinant of bacterial physiology. Adv. Microb. Physiol. 2001, 45, 199-270. [CrossRef] [PubMed]

13. Williams, P.; Winzer, K.; Chan, W.C.; Camara, M. Look who's talking: Communication and quorum sensing in the bacterial world. Philos. Trans. R. Soc. Lond. B Biol. Sci. 2007, 362, 1119-1134. [CrossRef] [PubMed]

14. Judd, S. The MBR Book: Principles and Applications of Membrane Bioreactors for Water and Wastewater Treatmen, 1st ed.; Elsevier Science: New York, NY, USA, 2006; ISBN 978-1-85617-481-7.

15. Lesjean, B.; Huisjes, E.H. Survey of the European MBR market: Trends and perspectives. Desalination 2008, 231, 71-81. [CrossRef]

16. Jarusutthirak, C.; Amy, G. Role of soluble microbial products (SMP) in membrane fouling and flux decline. Environ. Sci. Technol. 2006, 40, 969-974. [CrossRef] [PubMed]

17. Le-Clech, P.; Chen, V.; Fane, T.A.G. Fouling in membrane bioreactors used in wastewater treatment. J. Membr. Sci. 2006, 284, 17-53. [CrossRef] 
18. Meng, F.; Chae, S.-R.; Drews, A.; Kraume, M.; Shin, H.-S.; Yang, F. Recent advances in membrane bioreactors (MBRs): Membrane fouling and membrane material. Water Res. 2009, 43, 1489-1512. [CrossRef] [PubMed]

19. Lade, H.; Paul, D.; Kweon, J.H. Isolation and molecular characterization of biofouling bacteria and profiling of quorum sensing signal molecules from membrane bioreactor activated sludge. Int. J. Mol. Sci. 2014, 15, 2255-2273. [CrossRef] [PubMed]

20. Davies, D.G.; Parsek, M.R.; Pearson, J.P.; Iglewski, B.H.; Costerton, J.W.; Greenberg, E.P. The involvement of cell-to-cell signals in the development of a bacterial biofilm. Science 1998, 280, 295-298. [CrossRef] [PubMed]

21. Yeon, K.-M.; Cheong, W.-S.; Oh, H.-S.; Lee, W.-N.; Hwang, B.-K.; Lee, C.-H.; Beyenal, H.; Lewandowski, Z. Quorum sensing: A new biofouling control paradigm in a membrane bioreactor for advanced wastewater treatment. Environ. Sci. Technol. 2009, 43, 380-385. [CrossRef] [PubMed]

22. Drews, A. Membrane fouling in membrane bioreactors-Characterisation, contradictions, cause and cures. J. Membr. Sci. 2010, 363, 1-28. [CrossRef]

23. Kim, S.-R.; Oh, H.-S.; Jo, S.-J.; Yeon, K.-M.; Lee, C.-H.; Lim, D.-J.; Lee, C.-H.; Lee, J.-K. Biofouling control with bead-entrapped quorum quenching bacteria in membrane bioreactors: Physical and biological effects. Environ. Sci. Technol. 2013, 47, 836-842. [CrossRef] [PubMed]

24. Lee, S.; Park, S.-K.; Kwon, H.; Lee, S.H.; Lee, K.; Chang Hyun, N.; Jo, S.J.; Oh, H.-S.; Park, P.-K.; Choo, K.-H.; et al. Crossing the border between laboratory and field: Bacterial quorum quenching for anti-biofouling strategy in an MBR. Environ. Sci. Technol. 2016, 50, 1788-1795. [CrossRef] [PubMed]

25. Oger, P.M.; Uroz, S. Screening for N-AHSL-based-signaling interfering enzymes. In Metagenomics: Methods and Protocols; Streit, W.R., Daniel, R., Eds.; Humana Press: New York, NY, USA, 2010; Volume 668, pp. $203-217$. ISBN 978-1-60761-822-5.

26. Oh, H.-S.; Yeon, K.-M.; Yang, C.-S.; Kim, S.-R.; Lee, C.-H.; Park, S.Y.; Han, J.Y.; Lee, J.K. Control of membrane biofouling in MBR for wastewater treatment by quorum quenching bacteria encapsulated in microporous membrane. Environ. Sci. Technol. 2012, 46, 4877-4884. [CrossRef] [PubMed]

27. Dong, Y.-H.; Wang, L.-H.; Zhang, L.-H. Quorum-quenching microbial infections: Mechanisms and implications. Philos. Trans. R. Soc. Lond. B Biol. Sci. 2007, 362, 1201-1211. [CrossRef] [PubMed]

28. Romero, M.; Mayer, C.; Muras, A.; Otero, A. Silencing bacterial communication through enzymatic quorum sensing inhibition. In Quorum Sensing vs Quorum Quenching: A Battle with No End in Sight; Kalia, V.C., Ed.; Springer: New Delhi, India, 2015; ISBN 978-81-322-1981-1.

29. Leadbetter, J.R.; Greenberg, E.P. Metabolism of acyl-homoserine lactone quorum-sensing signals by Variovorax paradoxus. J. Bacteriol. 2000, 182, 6921-6926. [CrossRef] [PubMed]

30. Romero, M.; Diggle, S.P.; Heeb, S.; Camara, M.; Otero, A. Quorum quenching activity in Anabaena sp. PCC 7120: Identification of AiiC, a novel AHL-acylase. FEMS Microbiol. Lett. 2008, 280, 73-80. [CrossRef] [PubMed]

31. Park, S.Y.; Kang, H.O.; Jang, H.S.; Lee, J.K.; Koo, B.T.; Yum, D.Y. Identification of extracellular $\mathrm{N}$-acylhomoserine lactone acylase from a Streptomyces sp. and its application to quorum quenching. Appl. Environ. Microbiol. 2005, 71, 2632-2641. [CrossRef] [PubMed]

32. Sio, C.F.; Otten, L.G.; Cool, R.H.; Diggle, S.P.; Braun, P.G.; Bos, R.; Daykin, M.; Camara, M.; Williams, P.; Quax, W.J. Quorum quenching by an N-acyl-homoserine lactone acylase from Pseudomonas aeruginosa PAO1. Infect. Immun. 2006, 74, 1673-1682. [CrossRef] [PubMed]

33. Sunder, A.V.; Kumar, A.; Naik, N.; Pundle, A.V. Characterization of a new Bacillus cereus ATUAVP1846 strain producing penicillin V acylase, and optimization of fermentation parameters. Ann. Microbiol. 2012, 62, 1287-1293. [CrossRef]

34. Kang, B.R.; Lee, J.H.; Ko, S.J.; Lee, Y.H.; Cha, J.S.; Cho, B.H.; Kim, Y.C. Degradation of acyl-homoserine lactone molecules by Acinetobacter sp. strain C1010. Can. J. Microbiol. 2004, 50, 935-941. [CrossRef] [PubMed]

35. Park, S.Y.; Hwang, B.J.; Shin, M.H.; Kim, J.A.; Kim, H.K.; Lee, J.K. N-acylhomoserine lactonase producing Rhodococcus spp. with different AHL-degrading activities. FEMS Microbiol. Lett. 2006, 261, 102-108. [CrossRef] [PubMed]

36. Uroz, S.; Oger, P.M.; Chapelle, E.; Adeline, M.-T.; Faure, D.; Dessaux, Y. A Rhodococcus qsdA-encoded enzyme defines a novel class of large-spectrum quorum-quenching lactonases. Appl. Environ. Microbiol. 2008, 74, 1357-1366. [CrossRef] [PubMed] 
37. Liu, D.; Thomas, P.W.; Momb, J.; Hoang, Q.Q.; Petsko, G.A.; Ringe, D.; Fast, W. Structure and specificity of a quorum-quenching lactonase (AiiB) from Agrobacterium tumefaciens. Biochemistry 2007, 46, 11789-11799. [CrossRef] [PubMed]

38. Dong, Y.H.; Xu, J.L.; Li, X.Z.; Zhang, L.H. AiiA, an enzyme that inactivates the acylhomoserine lactone quorum-sensing signal and attenuates the virulence of Erwinia carotovora. Proc. Natl. Acad. Sci. USA 2000, 97, 3526-3531. [CrossRef] [PubMed]

39. Dong, Y.H.; Gusti, A.R.; Zhang, Q.; Xu, J.L.; Zhang, L.H. Identification of quorum-quenching N-acyl homoserine lactonases from Bacillus species. Appl. Environ. Microbiol. 2002, 68, 1754-1759. [CrossRef] [PubMed]

40. d'Angelo-Picard, C.; Faure, D.; Penot, I.; Dessaux, Y. Diversity of $N$-acyl homoserine lactone-producing and -degrading bacteria in soil and tobacco rhizosphere. Environ. Microbiol. 2005, 7, 1796-1808. [CrossRef] [PubMed]

41. Dong, Y.H.; Zhang, L.H. Quorum sensing and quorum-quenching enzymes. J. Microbiol. 2005, 43, $101-109$. [PubMed]

42. Pana, J.; Huang, T.; Yao, F.; Huang, Z.; Powell, C.A.; Qiu, S.; Guan, X. Expression and characterization of aiiA gene from Bacillus subtilis BS-1. Microbiol. Res. 2008, 163, 711-716. [CrossRef] [PubMed]

43. Liu, D.; Momb, J.; Thomas, P.W.; Moulin, A.; Petsko, G.A.; Fast, W.; Ringe, D. Mechanism of the quorum-quenching lactonase (AiiA) from Bacillus thuringiensis. 1. Product-bound structures. Biochemistry 2008, 47, 7706-7714. [CrossRef] [PubMed]

44. Lade, H.; Paul, D.; Kweon, J.H. N-acyl homoserine lactone-mediated quorum sensing with special reference to use of quorum quenching bacteria in membrane biofouling control. BioMed Res. Int. 2014, 2014, 162584. [CrossRef] [PubMed]

45. Cesaro, A.; Russo, L.; Belgiorno, V. Combined anaerobic/aerobic treatment of OFMSW: Performance evaluation using mass balances. Chem. Eng. J. 2015, 267, 16-24. [CrossRef]

46. Zuriaga-Agusti, E.; Mendoza-Roca, J.A.; Bes-Pia, A.; Alonso-Molina, J.L.; Fernandez-Gimenez, E.; Alvarez-Requena, C.; Munagorri-Manueco, F.; Ortiz-Villalobos, G. Comparison between mixed liquors of two side-stream membrane bioreactors treating wastewaters from waste management plants with high and low solids anaerobic digestion. Water Res. 2016, 100, 517-525. [CrossRef] [PubMed]

47. Young, J.P.; Downer, H.L.; Eardly, B.D. Phylogeny of the phototrophic Rhizobium strain BTAi1 by polymerase chain reaction-based sequencing of a 16S rRNA gene segment. J. Bacteriol. 1991, 173, 2271-2277. [CrossRef] [PubMed]

48. Thompson, J.D.; Higgins, D.G.; Gibson, T.J. CLUSTAL-W-Improving the sensitivity of progressive multiple sequence alignment through sequence weighting, position-specific gap penalties and weight matrix choice. Nucleic Acids Res. 1994, 22, 4673-4680. [CrossRef] [PubMed]

49. McClean, K.H.; Winson, M.K.; Fish, L.; Taylor, A.; Chhabra, S.R.; Camara, M.; Daykin, M.; Lamb, J.H.; Swift, S.; Bycroft, B.W.; et al. Quorum sensing and Chromobacterium violaceum: Exploitation of violacein production and inhibition for the detection of N-acylhomoserine lactones. Microbiology 1997, 143, 3703-3711. [CrossRef] [PubMed]

50. Ravn, L.; Christensen, A.B.; Molin, S.; Givskov, M.; Gram, L. Methods for detecting acylated homoserine lactones produced by Gram-negative bacteria and their application in studies of AHL-production kinetics. J. Microbiol. Methods 2001, 44, 239-251. [CrossRef]

51. Watson, B.; Currier, T.C.; Gordon, M.P.; Chilton, M.D.; Nester, E.W. Plasmid required for virulence of Agrobacterium tumefaciens. J. Bacteriol. 1975, 123, 255-264. [PubMed]

52. Steindler, L.; Venturi, V. Detection of quorum-sensing $N$-acyl homoserine lactone signal molecules by bacterial biosensors. FEMS Microbiol. Lett. 2007, 266, 1-9. [CrossRef] [PubMed]

53. Merritt, J.H.; Kadouri, D.E.; O'Toole, G.A. Growing and analyzing static biofilms. Curr. Protoc. Microbiol. 2005, 1, 1B. 1.1-1B. 1.17. [CrossRef]

54. Stepanovic, S.; Vukovic, D.; Dakic, I.; Savic, B.; Svabic-Vlahovic, M. A modified microtiter-plate test for quantification of staphylococcal biofilm formation. J. Microbiol. Methods 2000, 40, 175-179. [CrossRef]

55. Romero, M.; Martin-Cuadrado, A.-B.; Roca-Rivada, A.; Maria Cabello, A.; Otero, A. Quorum quenching in cultivable bacteria from dense marine coastal microbial communities. FEMS Microbiol. Ecol. 2011, 75, 205-217. [CrossRef] [PubMed] 
56. Romero, M.; Muras, A.; Mayer, C.; Bujan, N.; Magarinos, B.; Otero, A. In vitro quenching of fish pathogen Edwardsiella tarda AHL production using marine bacterium Tenacibaculum sp. strain 20J cell extracts. Dis. Aquat. Org. 2014, 108, 217-225. [CrossRef] [PubMed]

57. Ortori, C.A.; Atkinson, S.; Chhabra, S.R.; Camara, M.; Williams, P.; Barrett, D.A. Comprehensive profiling of $N$-acylhomoserine lactones produced by Yersinia pseudotuberculosis using liquid chromatography coupled to hybrid quadrupole-linear ion trap mass spectrometry. Anal. Bioanal. Chem. 2007, 387, 497-511. [CrossRef] [PubMed]

58. Torres, M.; Romero, M.; Prado, S.; Dubert, J.; Tahrioui, A.; Otero, A.; Llamas, I. N-acylhomoserine lactone-degrading bacteria isolated from hatchery bivalve larval cultures. Microbiol. Res. 2013, 168, 547-554. [CrossRef] [PubMed]

59. Milton, D.L.; Chalker, V.J.; Kirke, D.; Hardman, A.; Camara, M.; Williams, P. The LuxM Homologue vanM from Vibrio anguillanrum directs the synthesis of N-(3-hydroxyhexanoyl) homoserine lactone and N-hexanoylhomoserine lactone. J. Bacteriol. 2001, 183, 3537-3547. [CrossRef] [PubMed]

60. Hormigo, D.; De La Mata, I.; Castillon, M.P.; Acebal, C.; Arroyo, M. Kinetic and microstructural characterization of immobilized penicillin acylase from Streptomyces lavendulae on Sepabeads EC-EP. Biocatal. Biotransform. 2009, 27, 271-281. [CrossRef]

61. Torres, R.; Ramon, F.; de la Mata, I.; Acebal, C.; Castillon, M.P. Enhanced production of penicillin V acylase from Streptomyces lavendulae. Appl. Microbiol. Biotechnol. 1999, 53, 81-84. [CrossRef] [PubMed]

62. Oh, H.-S.; Kim, S.-R.; Cheong, W.-S.; Lee, C.-H.; Lee, J.-K. Biofouling inhibition in MBR by Rhodococcus sp. BH4 isolated from real MBR plant. Appl. Microbiol. Biotechnol. 2013, 97, 10223-10231. [CrossRef] [PubMed]

63. Yates, E.A.; Philipp, B.; Buckley, C.; Atkinson, S.; Chhabra, S.R.; Sockett, R.E.; Goldner, M.; Dessaux, Y.; Camara, M.; Smith, H.; et al. N-acylhomoserine Lactones undergo lactonolysis in a $\mathrm{pH}-$, temperature-, and acyl chain length-dependent manner during growth of Yersinia pseudotuberculosis and Pseudomonas aeruginosa. Infect. Immun. 2002, 70, 5635-5646. [CrossRef] [PubMed]

64. Mukherji, R.; Varshney, N.K.; Panigrahi, P.; Suresh, C.G.; Prabhune, A. A new role for penicillin acylases: Degradation of acyl homoserine lactone quorum sensing signals by Kluyvera citrophila penicillin $\mathrm{G}$ acylase. Enzym. Microb. Technol. 2014, 56, 1-7. [CrossRef] [PubMed]

65. Torres, R.; de la Mata, I.; Castillon, M.P.; Arroyo, M.; Torres, J.; Acebal, C. Purification and characterization of penicillin V acylase from Streptomyces lavendulae. In Stability and Stabilization of Biocatalysts; Ballesteros, A., Plou, F.J., Iborra, J.L., Halling, P.J., Eds.; Elsevier: Amsterdam, The Netherlands, 1998; Volume 15, pp. 719-724. ISBN 0-444-82970-9.

66. Torres-Bacete, J.; Hormigo, D.; Torres-Guzman, R.; Arroyo, M.; Pilar Castillon, M.; Luis Garcia, J.; Acebal, C.; de la Mata, I. Overexpression of Penicillin V Acylase from Streptomyces lavendulae and elucidation of its catalytic residues. Appl. Environ. Microbiol. 2015, 81, 1225-1233. [CrossRef] [PubMed]

67. Cheong, W.-S.; Lee, C.-H.; Moon, Y.-H.; Oh, H.-S.; Kim, S.-R.; Lee, S.H.; Lee, C.-H.; Lee, J.-K. Isolation and identification of indigenous quorum quenching bacteria, Pseudomonas sp. 1A1, for biofouling control in MBR. Ind. Eng. Chem. Res. 2013, 52, 10554-10560. [CrossRef]

68. Chong, G.; Kimyon, O.; Rice, S.A.; Kjelleberg, S.; Manefield, M. The presence and role of bacterial quorum sensing in activated sludge. Microb. Biotechnol. 2012, 5, 621-633. [CrossRef] [PubMed]

69. Kim, A.L.; Park, S.-Y.; Lee, C.-H.; Lee, C.-H.; Lee, J.-K. Quorum quenching bacteria isolated from the sludge of a wastewater treatment plant and their application for controlling biofilm formation. J. Microbiol. Biotechnol. 2014, 24, 1574-1582. [CrossRef] [PubMed]

70. Muras, A.; Lopez-Perez, M.; Mayer, C.; Parga, A.; Amaro-Blanco, J.; Otero, A. High prevalence of quorum-sensing and quorum-quenching activity among cultivable bacteria and metagenomic sequences in the Mediterranean Sea. Genes 2018, 9, 100. [CrossRef] [PubMed]

71. Li, Y.-S.; Cao, J.-S.; Li, B.-B.; Li, W.-W.; Fang, F.; Tong, Z.-H.; Yu, H.-Q. Outcompeting presence of Acyl-Homoserine-Lactone (AHL)-quenching bacteria over AHL-producing bacteria in aerobic granules. Environ. Sci. Technol. Lett. 2016, 3, 36-40. [CrossRef]

72. Feugeas, J.-P.; Tourret, J.; Launay, A.; Bouvet, O.; Hoede, C.; Denamur, E.; Tenaillon, O. Links between transcription, environmental adaptation and gene variability in Escherichia coli: Correlations between gene expression and gene variability reflect growth efficiencies. Mol. Biol. Evol. 2016, 33, 2515-2529. [CrossRef] [PubMed] 
73. Park, S.Y.; Lee, S.J.; Oh, T.K.; Oh, J.W.; Koo, B.T.; Yum, D.Y.; Lee, J.K. AhlD, an N-acylhomoserine lactonase in Arthrobacter sp., and predicted homologues in other bacteria. Microbiology-SGM 2003, 149, 1541-1550. [CrossRef] [PubMed]

74. Uroz, S.; d'Angelo-Picard, C.; Carlier, A.; Elasri, M.; Sicot, C.; Petit, A.; Oger, P.; Faure, D.; Dessaux, Y. Novel bacteria degrading $N$-acylhomoserine lactones and their use as quenchers of quorum-sensing-regulated functions of plant-pathogenic bacteria. Microbiology-SGM 2003, 149, 1981-1989. [CrossRef] [PubMed]

75. Uroz, S.; Chhabra, S.R.; Camara, M.; Williams, P.; Oger, P.; Dessaux, Y. N-acylhomoserine lactone quorum-sensing molecules are modified and degraded by Rhodococcus erythropolis W2 by both amidolytic and novel oxidoreductase activities. Microbiology-SGM 2005, 151, 3313-3322. [CrossRef] [PubMed]

76. Rolinson, G.; Richards, M.; Batchelor, F. Production of 6-Aminopenicillanic Acid. U.S. Patent 3014845, 3014846, 26 December 1961.

77. Sunder, A.V.; Utari, P.D.; Ramasamy, S.; van Merkerk, R.; Quax, W.; Pundle, A. Penicillin V acylases from Gram-negative bacteria degrade $\mathrm{N}$-acylhomoserine lactones and attenuate virulence in Pseudomonas aeruginosa. Appl. Microbiol. Biotechnol. 2017, 101, 2383-2395. [CrossRef] [PubMed]

78. Algburi, A.; Zehm, S.; Netrebov, V.; Bren, A.B.; Chistyakov, V.A.; Chikindas, M.L. Subtilosin prevents biofilm formation by inhibiting bacterial quorum sensing. Probiotics Antimicrob. Proteins 2017, 9, 81-90. [CrossRef] [PubMed]

(C) 2018 by the authors. Licensee MDPI, Basel, Switzerland. This article is an open access article distributed under the terms and conditions of the Creative Commons Attribution (CC BY) license (http://creativecommons.org/licenses/by/4.0/). 